\title{
The investment prospects of Uzbekistan
}

\author{
Mukhammadkhon Soliev
}

\author{
Innovative Center, Head of Academy \\ DOI: 10.29322/IJSRP.10.03.2020.p9911 \\ http://dx.doi.org/10.29322/IJSRP.10.03.2020.p9911
}

\begin{abstract}
This research empirically demonstrates the current status quo of investment environment and potential of Uzbekistan - one of the dynamically developing countries of Asia. By providing relevant and clear evidences of investment prospective of country and highlighting main features of national economy, paper aims to investigate primary important factors, which stands for paradoxical growth and some actual problems as well. The results serve to point out key trends and gaps in which to focus future research on this topic and they might be useful in formulating public policies and strategies for further defining of investment potential and economic development of country.
\end{abstract}

Index Terms- Investment, Foreign investor, Uzbekistan, Invest potential, developing countries, Central Asia.

\section{INTRODUCTION}

$\mathrm{T}$ The last decade have seen an incredibly successful to one of the largest economies of Central Asian region-Uzbekistan dynamic growth of GDP around 8\%, negligible amount of domestic and international debt, underestimated exchange rate and even more interestingly relatively distribution of income. (Vladimir Popov, 2014) Moreover the foreign direct investments, which is considered as a vital factor of growth in many newly developing countries, is become one of the primary part of national investment policy of states with transition economy like Uzbekistan. On this basis, the government has done successful implementation the notion of free investment climate into legislature by inaugurating different acts and laws, which regulate flow of sources and simultaneously help foreign investors by providing various forms of information. (B. B. Valiev, 2014)

Conservatively, it is widely held perception that oil and gas industry are the main sectors of economy and paramount source of people's welfare. The lion's share of national economy, such as heavy and light industry excessively rely on fuel industry. Equally importantly, Uzbekistan proclaimed and currently is working under executing national program called 'On the priorities of industrial development for 2011-2015' which accumulates more than 500 most-promising invest-projects, which assessed approximately 50 Billion USD. (Parpiev, 2014)Summarizing the annual results for 9 month 2014, the implementation of the State Investment Program approved by government in the share of attraction of foreign investments extended $102,7 \%$ over the yearly prognosis.

Main part of foreign investments was put into the following sectors of economy:

$>$ oil and gas $64,8 \%$
$>$ power generation $6,6 \%$

$>$ telecommunication and IT-technology $4,7 \%$

$>$ credit lines for the development of small business entities $4,7 \%$

$>\operatorname{road}$ construction $4,4 \%$

$>$ drinking water supply and sewage 3,8\%

$>$ construction and construction materials $3,1 \%$

$>$ agriculture and water management $2,1 \%$

$>$ textile $1,9 \%$

The majority of investment projects have been done in the collaboration with more than 30 countries all over the world such as China, Germany, South Korea, Japan, Netherlands, Great Britain, Malaysia, and Russia etc. («MFERIT - Statistics investing activities»,) Uzbekistan

Background information about investment potential in

As one of the Central Asian countries Uzbekistan possesses a range amount of natural and mineral resources as well as pleasing weather, extraordinary background, hospitality, multiculturalism, tourism and recreation infrastructure like hotels and international class airports which highlight economic potential of state. It is also one of the few and unique countries which combines the high living standards, comprehensive medical care and sophisticated education system and minimum cost of living. In addition, Uzbekistan is the country which is well known for the greatest towns with hundreds of architectural monuments of different epochs. Samarkand, Tashkent, Bukhara, Khiva and other cities are regarded as the main industrial trade centers of country and architectural heritages of the world as well.

According to statistics given by states in 2014, there was a remarkable increase by $8.1 \%$ (Table 1), making it in marginal advantage over the results that demonstrated in 2013. Strike encountered in Russian federation has directly exerted on lesser growth owing to fact that Russia represents as one of the major trade companions as well as big contributor of finance transmission. As a result, depletion occurred in both external and internal scales in trade and remittance. Moreover, lower income from export expedited devaluation of the Uzbek sum toward the US Dollar. States, however, in order to keep interior demand, augmented expenditures to public and commercial loaning. In balance, two deployment industry and services benefited most, while industry's rate revealed slight decrease from $8.8 \%$ in 2013 to $8.3 \%$ in following year with eliminating from construction, from $13.7 \%$ in 2013 to 15.4 has increased the percentage of services. Due to current condition of modernization program that is implementing in industry by tremendous assistance of public investment, there was a huge contribution in production of 
machinery, metals and chemical, thereby surged to $10.2 \%$ and made approximately $40 \%$ of entire production. As regard to services, nucleus output has seen in information and communication technology with $24.1 \%$ and finance strongly backed from demand as well as local lending. («Macroeconomic indicators of the Republic of Uzbekistan»)

Table 1. Macroeconomic indicators in January-September 2014

\begin{tabular}{|l|l|l|}
\hline & Billion. UZS & $\begin{array}{l}\text { Annual } \\
\text { growth } \\
\text { comparing } \\
\text { with } \\
\text { previous } \\
\text { year }\end{array}$ \\
\hline Gross domestic product & 100309,5 & $8,1 \%$ \\
\hline Industrial output & & $8,4 \%$ \\
\hline
\end{tabular}

\begin{tabular}{|l|l|l|}
\hline Agricultural output & 28094,5 & $6,8 \%$ \\
\hline Investments in fixed capital & 23831,2 & $10,7 \%$ \\
\hline Construction work & 15034,6 & $18,9 \%$ \\
\hline Retail trade turnover & 41664,3 & $4,2 \%$ \\
\hline Services, total & 57197,2 & $4,7 \%$ \\
\hline
\end{tabular}

Source: The State Committee of the Republic of Uzbekistan on Statistics

Trade and catering that are considered as an important subsector has amplified with $17.5 \%$. Awful weather condition, though, was not impediment for yielding a positive account in agriculture which demonstrated a better output assimilating to production of 2013 owing to healthy vegetable yields and enhancement of livestock goods. Complements in emoluments and pensions, public investment mercantile loaning were main assistance in growth of demand within country. Private intake has remained as a result of $19.1 \%$ escalation in public sector salaries.

Table 2. Index of External Trade Turnover

\begin{tabular}{|l|l|l|}
\hline & Amount ( in million USD) & $\begin{array}{l}\text { Annual growth comparing with } \\
\text { previous year }\end{array}$ \\
\hline External trade turnover. & 21277,0 & $0,6 \%$ \\
\hline Exports & 11096,9 & $0,2 \%$ \\
\hline Imports & 10180,1 & $0,9 \%$ \\
\hline Balance & 916,8 & \\
\hline
\end{tabular}

Source: The State Committee of the Republic of Uzbekistan on Statistics

Total trade turnover of country which calculated by adding quantity of exports and imports of state reached 21,2 billion USD with the $0,6 \%$ growth in comparison with analog period of previous year. The balance of export and import is positive, about 916 million USD with 11,1 billion USD against 10,1 billion USD respectively. But annual growth of imports is more than export rise, $0,9 \%$ versus $0,2 \%$.

Moreover, Gross fixed finance foundation has enlarged by $10.9 \%$. Investment taken by foreign businessmen has comprised just under $\$ 3.0$ billion, from total $\$ 14.6$ billion capital investment. There were perceptible assignments that aid to escalate the economy of Uzbekistan. First of all, project of extension of the General Motors Uzbekistan car manufacturing that has perfected in 2014. In order to supply gas to the People's Republic of China gas pipeline has launched and already terminated. This gas channel will bond Central Asia with the Republic of China. Furthermore, the serious considerable upturns were seen in pecuniary lending by commercial banks elevated to $31.2 \%$, while by official report that has done by the state there was $6.1 \%$ as average per annum in inflation rate in last year. Depletion in price of food in a global scale eventuated slow inflation in official consumer price. According to certified information presented by the International Monetary Fund, there were quiet different ratios with lessening in inflation rate from $11.2 \%$ in 2013 to $8.4 \%$ currently. It is expected to have a rise in fourth quarter as a result of devaluation of Uzbek sum to US dollar. As regard to informal restraint market ratio, national currency lose its worth in one fifth in previous year with last quarter being poised as a high point of acceleration, though owing to reduction in price of global fuel. However, the Central Bank of Uzbekistan responded by expediting official depreciation of currency to US dollar and legislated a strict regulation related to import controls.

The similar rise has encountered in percentage of 20132014 year's broad money with $26 \%$ in both years, thus accentuating greater domestic credit. Questionnaire made to calculate finance as broad money is not accessible, though quota of foreign tenures within banking system might fall in quantity as a result of overcoming in rate of domestic credit over broad money. As to 2014 budget surplus in GDP of country was at level of $0.2 \%$ relying on data proliferated by government. It has been computed that advanced budget balance have comprised $2.4 \%$ surplus of GDP in 2014, making it barely less than results of 2013 with $2.7 \%$. Annual income to budget has seen depletion in $0.1 \%$ in 2014 year comparing to rate of 2013 year with $36.1 \%$ and $36.2 \%$ respectively. Similarly, prices for international major export goods was in minus as well. Consecrating funds to escalate the compartments of wages, pensions, health care as well as education have composed a great bulk from entire budget making enhancement in allocation of expenditure from $33.5 \%$ of GDP in 2013 and $33.7 \%$ of GDP in following year. Moreover as a result of enlargement in the share of loaning finance from external sources the sheer governmental debt has increased in this account. Ongoing states surplus assessed to comprise smaller percentage to last year repercussions, thereby portraying lesser trade surplus as 
well as minor remittances. Exterior markets' requirement for local commodities from Uzbekistan was frail as usual, while key export goods have crossed margin of debilitation as it have been ever before. This phenomenon emerged after presenting reduction in output from energy that compiles almost $30 \%$ of exports. Detailed looking at the number of exports, it will be apparent that exhaustion in price for energy has followed the identical trend in global oil prices. Whole exports in other words abridged to 2.0\%, which mainly on account of progress of the economy in Russian Federation where remittances have also suffered a considerable diminution. Frail consumer demand and swift nominal appreciation of the Uzbek sum to Russian ruble have resulted in suffering depreciation in bilateral trade. Dwindling of remittances from Russia that is estimated to compose $10 \%$, in other words up to $\$ 5.0$ billion, which was mainly dumped on account of thinning of labor demand in construction and logistics. The key two commodities that account for lion's share of importing goods were consumer goods and chemicals. The whole trend of imports went up by $1.1 \%$, in contempt of reduction in quantum of machinery and equipment to about $10 \%$ assimilating to 2013 , these aspects held a nucleus position counting for $40 \%$ of entire import rate. If we look in details of import goods (Figure 1), it could be noticed the prevalent role of machinery and chemical industries which occupy more than half part of total.

\section{Figure 1.}

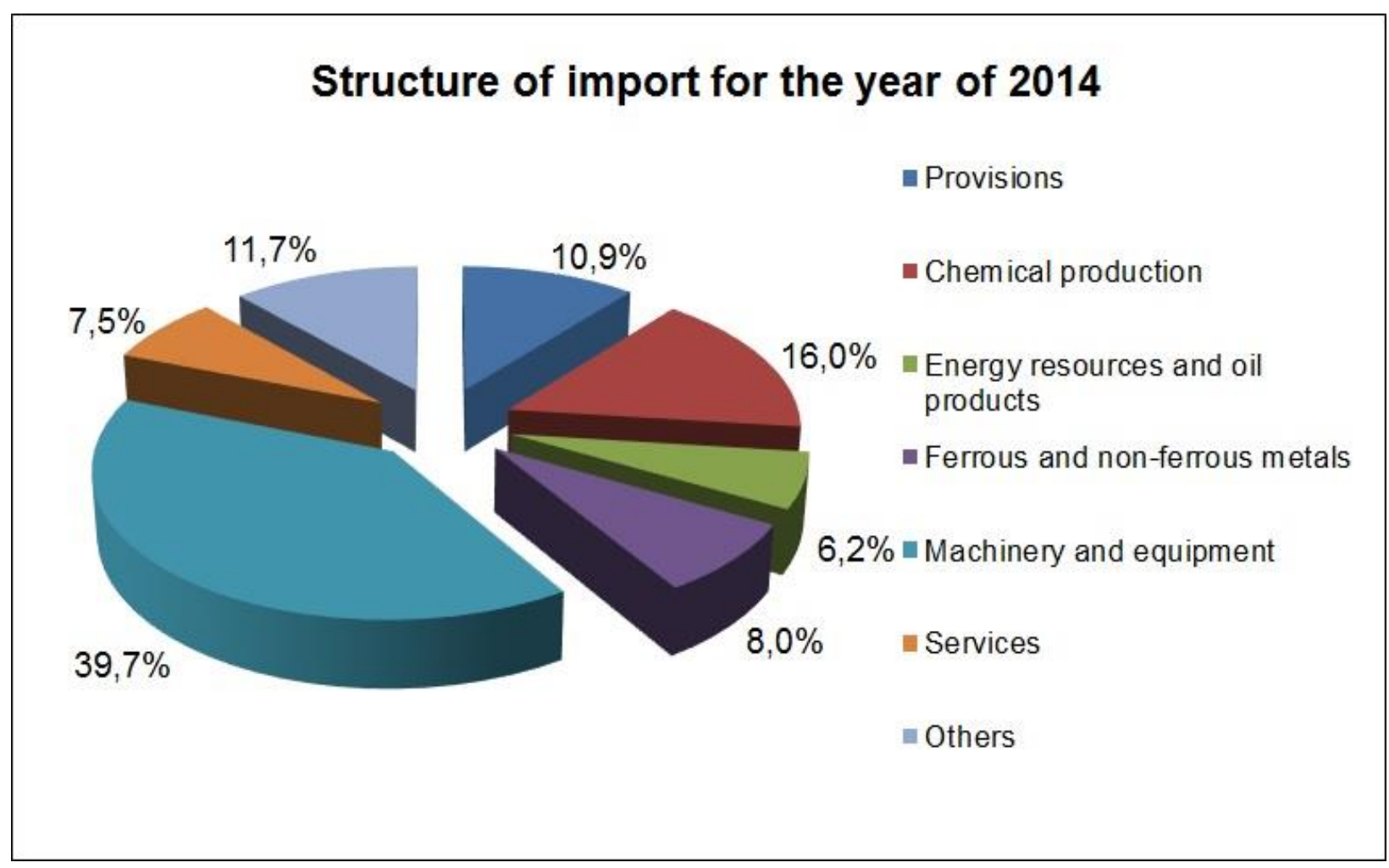




\section{Figure 2.}

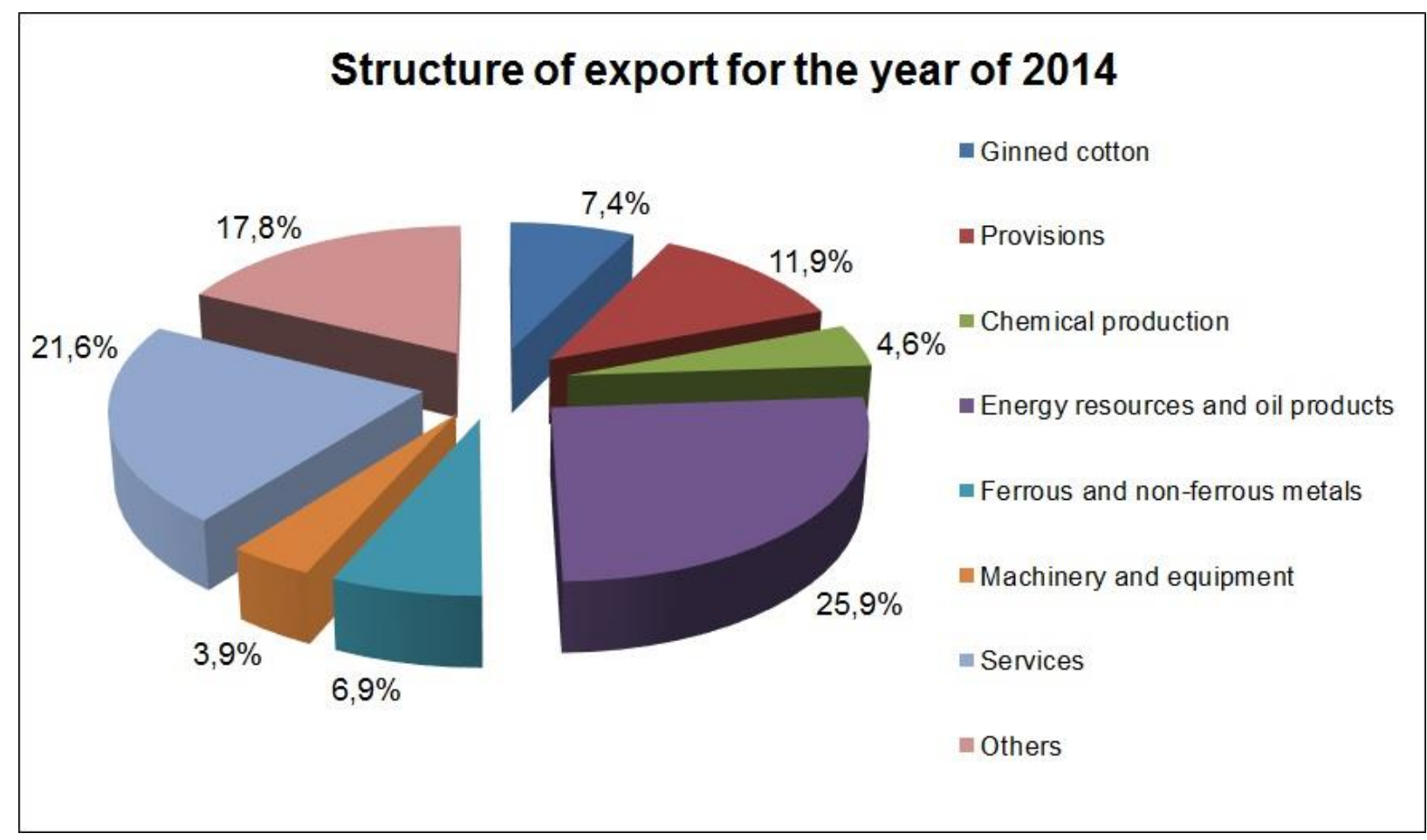

In contrary, Figure 2, which reveals the share of various industries into total export goods of country, is predominated by raw materials-based industries and energy resources. Also, machinery equipment and chemical production have significant contribution to export consistency of state.

Main industries which appeal investors. Promising investment projects

Having possessed an enormous investment potential, Uzbekistan also has an adequate distribution of this financial sources into various forms of industry. Government pay a great deal of attention for appropriate investment of strategic sectors of economy and serves as a catalyst between entrepreneurs and foreign investors.

In general, the investment attractiveness of different forms of Uzbek national economy is pre-disposed due to the following reasons:

- Relatively low cost the basic thing which is necessary for manufacturing ( price for a thousand cubic meters of natural gas is about $\$ 37$, price for one megawatt of power is $\$ 35$, average real salary in the country is $\$ 300$ )
- Considerable domestic market -about 31 million people who live permanently(«Uzbekistan population 2015 | Current population of Uzbekistan»,)

- Free access to the CIS(Commonwealth of Independent States) which population is more than 280 million

One of the key evidences which represents invest opportunity in Uzbekistan could be found in official report of Ministry Of Foreign Economic Relations, Investments and Trade of the Republic of Uzbekistan. According to this report, the total amount of projected investment proposals evaluated as much as 5,886 Billion USD and this is only short-term invests from different financial organizations around the world. («MFERIT Promising investment projects»,) The Table 1 presents information about most valuable and promising projects of investment, each line shows only major projects which accumulate more than 50 million USD. The mains sector of economy which appeal the main part of direct foreign investments are - complex of geology, energy, chemical, petrochemical and metallurgical industries (about 30 percent) and the complex of development of mechanical, electrical engineering and aviation industry, standardization of products(its market's share is not completely assessed).

Table 3. Most Promising invest projects (Table includes only projects which cost more than 50 million USD)

\begin{tabular}{|l|l|l|l|l|}
\hline $\mathrm{N}$ & Name of project & Initiator & $\begin{array}{l}\text { Cost of } \\
\text { project } \\
\text { (Million } \\
\text { USD) }\end{array}$ & $\begin{array}{l}\text { Evaluated } \\
\text { period of } \\
\text { implementation }\end{array}$ \\
\hline
\end{tabular}




\begin{tabular}{|c|c|c|c|c|}
\hline 1. & $\begin{array}{l}\text { Organization of production of polymers } \\
\text { (polycarbonate, polystyrene, ABS- } \\
\text { plastics and etc.) on the basis of deep } \\
\text { processing of hydrocarbons }\end{array}$ & $\begin{array}{l}\text { "Uzbekneftegaz" } \\
\text { National Holding } \\
\text { Company }\end{array}$ & 700,00 & $2015-2016$ \\
\hline 2. & $\begin{array}{l}\text { Conduction of exploration works on Akjar } \\
\text { and Chimbay investment blocks of } \\
\text { Uzbekistan }\end{array}$ & $\begin{array}{l}\text { "Uzbekneftegaz" } \\
\text { National } \quad \text { Holding } \\
\text { Company }\end{array}$ & 56,10 & 2014-2017 \\
\hline 3. & $\begin{array}{l}\text { Conduction of exploration works of oil } \\
\text { and gas bearing investment blocks } \\
(\text { Khorezm and Meshekli-Tuzkoy } \\
\text { investment blocks) of the Republic of } \\
\text { Uzbekistan }\end{array}$ & $\begin{array}{l}\text { "Uzbekneftegaz" } \\
\text { National Holding } \\
\text { Company }\end{array}$ & 200,00 & 2014-2018 \\
\hline 4. & $\begin{array}{l}\text { Implementation of projects to increase oil } \\
\text { recovery from long-developed fields with } \\
\text { hard extractable reserves (application of } \\
\text { new methods of oil recovery) }\end{array}$ & $\begin{array}{l}\text { "Uzbekneftegaz" } \\
\text { National } \quad \text { Holding } \\
\text { Company }\end{array}$ & 151,47 & $2014-2020$ \\
\hline 5. & $\begin{array}{l}\text { Organization of production } \\
\text { polycrystalline silicon }\end{array}$ & "Uzkimesanoat" SJSC & 400,00 & 2014-2017 \\
\hline 6. & $\begin{array}{l}\text { Development of Tebinbulak deposit with } \\
\text { further production of cast-iron (In } \\
\text { association with State Committee of } \\
\text { Geology and Mineral Resources) }\end{array}$ & "Uzmetkombinat" OJSC & 3100,00 & $2013-2020$ \\
\hline 7. & $\begin{array}{l}\text { Production of units and components for } \\
\text { automotive power } \begin{array}{r}\text { packages } \\
\text { (transmissions) }\end{array}\end{array}$ & "Uzavtosanoat" JSC & 310,00 & $2014-2015$ \\
\hline 8. & Organization of production of basic glass & "Uzavtosanoat" JSC & 90,00 & $2014-2016$ \\
\hline 9. & $\begin{array}{l}\text { Establishment of textile complex using } \\
\text { the facilities of unfinished construction in } \\
\text { Dzhondor district of Bukhara region }\end{array}$ & $\begin{array}{l}\text { "O'zbekyengilsanoat" } \\
\text { SJSC }\end{array}$ & 65,50 & 2014-2015 \\
\hline 10. & $\begin{array}{l}\text { Establishment of textile } \\
\text { complex using the facilities } \\
\text { of unfinished construction in } \\
\text { Shafirkan district of Bukhara } \\
\text { region }\end{array}$ & $\begin{array}{l}\text { "O'zbekyengilsanoat" } \\
\text { SJSC }\end{array}$ & 66,50 & 2014-2015 \\
\hline 11. & $\begin{array}{l}\text { Establishment of the textile complex on } \\
\text { production of finished fabrics and textiles } \\
\text { in Kashkadarya region. }\end{array}$ & $\begin{array}{l}\text { "O'zbekyengilsanoat" } \\
\text { SJSC }\end{array}$ & 50,00 & 2014-2015 \\
\hline
\end{tabular}

Oil-and-gas industry

As it can be concluded from Table 1, the most attractive sector of economy for foreign investors is oil-gas industry. National Holding Company (NHC) "Uzbekneftegaz" which accumulate 6 major joint shareholding companies, including more than 120 entrepreneurships in the complex, controls oil and gas industry in country.

The complex performs exploration, investigative drilling and drilling of oil and gas wells production, oil and gas fields improvement, oil, production of gas and gas condensate, natural gas processing, carriage and gas underground storage, administration of the facilities that transport natural gas from Uzbek gas producers to local consumers and overseas, as well as providing transit of the natural gas from neighbor countries, project works, cardinal construction and development of production, transport, oil and gas processing facilities, oil products are realized to economy sectors and population of the country, the production of engineering products for businesses and organizations of oil and gas and gas chemical complexes. The state is the major stake holder of the company. («Structure of Uzbekneftgaz»)

The main oil and gas bearing region of the country can be divided into five districts:

- Ustyurtsky,

- Bukhara-Khiva,

- Hissar,

- Surkhandarya

- Ferghana 
This regions combine more than 232 discovered deposits of oil, gas and gas condensate. Except of them, 103 are being developed, 60 - equipped for development, and 69 are in the process of research. Moreover, the country possesses a widespread gas transportation system. The total length of gas pipeline is more than 13 thousand $\mathrm{km}$ and about 250 compressor stations are located on their way. («Industry - Uzbekistan»)

Chemical industry

The other attractive sphere of Uzbek economy is chemical industry, which aggregate enterprises producing fertilizers, chemical fibers, synthetic resins, polymer products and also plant protection chemicals. Like oil-gas industry it controlled by State Joint Stock Company (SJSC) "Uzkimyosanoat.", which integrate 12 primary industrial companies, 13 regional distribution enterprises and also different academic institution along with transportation organization. products:

Currently, SJSC enterprises are producing the following

- Mineral fertilizers and inorganic products (nitrogen, phosphate potash fertilizers, ammonia, caustic soda and soda ash);

- Organic chemistry, synthetic fibers and polymer materials (cellulose and cellulose acetate, fiber, acetate yarns, polyethylene products);

- Chemicals for energy and chemical industries, as well as for gold production (sodium cyanide, thiourea, polyacrylamides, azotic, sulfuric, hydrochloric acid, catalysts, acetic acid, acetylene, etc.); - Chemical-based plant protection products (chlorate magnesium defoliant) («By Industry | "UZINFOINVEST" the Information Support \& Foreign Investments Promotion Agency»,)
Automobile manufacturing and engineering industries

One of the fast developing branch of industry - automotive manufacturing industry is epresented and monitored by Joint Stock Company "Uzavtosanoat.". This concern collect 21 enterprises and organization and institution of tertiary education Turin Polytechnic University in Tashkent. This sphere, which has surged in recent times exponentially and induce internal growth in demand of vehicles as well as enhanced its share in the global market. In collaboration with multinational companies such as GM , ISUZU, MAN, MERCEDES BENZ, national regulator modernize current material base of plants, factories which aggravate in itself. («Structure of Uzauto»)

Legal procedure of registration investment activity in Uzbekistan

The main licit document, which provides information about guarantees and privileges in each particular case, is - investment agreement which is concluded between the Government of the Republic of Uzbekistan and foreign investor (Figure 3). This legal act instructs rights, duties and responsibility of entrepreneurships with regard to their investment activity. The responsible body which represents the country and conclude investment is Ministry of foreign economic relations, investments and trade of the Republic of Uzbekistan. Moreover, the negotiation can also include list of other measures and protections to those requires by the legislation, for instance, creation special custom, reducing the burden of tax and payments regime, forming the state monitoring on execution of investment projects. («Procedure of investment agreements conclusion and fulfillment | "UZINFOINVEST" the Information Support \& Foreign Investments Promotion Agency»)

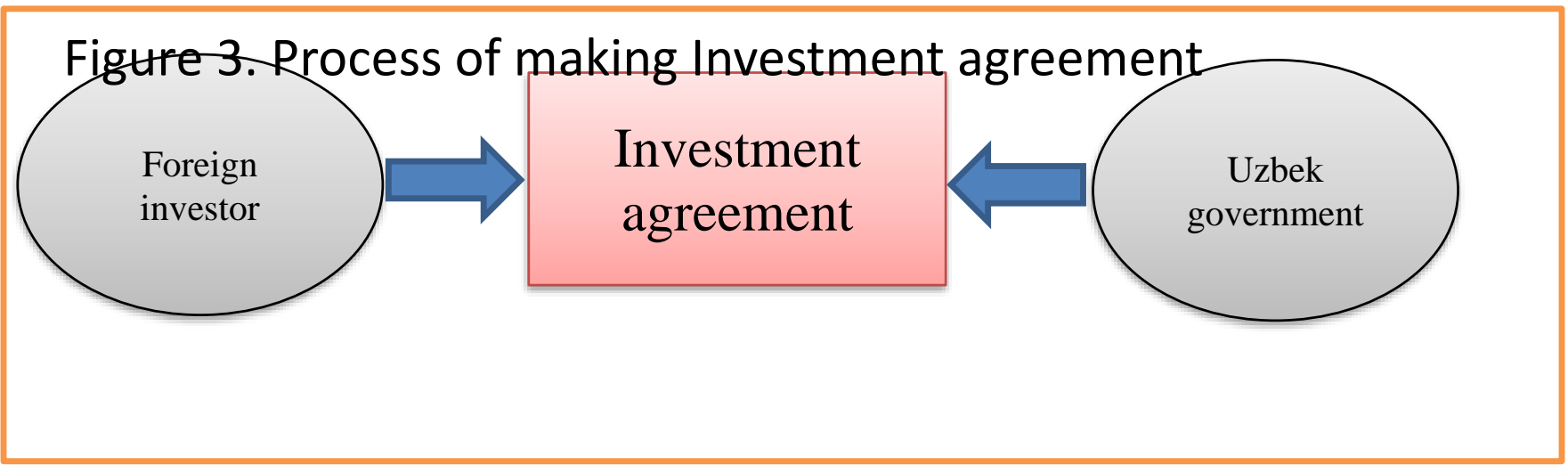

According to legislation of country (Government decree №180, 02/08/2005) investment agreement should include following information:

- Object and capacity of investment sources;

- Terms, conditions and period of validity of investment agreement;

- the investor's privileges and responsibilities, including those concerning: a capacity of financing, warranting a particular size of production, quality of product and guaranteed level of localization, labor rights and protective measures and other lines of its activity. - both privileges and responsibilities of the Government of the Republic of Uzbekistan, including rights and obligations on granting of guarantees and safety measures excessively to those specified by the legislature;

- information on term of preparation of design estimations, conclusion of agreements for contractor's work, foundations of funding, timetable of contentment of the mission, a technique for practical supervision of the sequence of gratification of investment project;

- process and terms of presentation by the foreign investor of reports on the sequence of fulfillment of his responsibilities;

- responsibility of the parties for non-observance of circumstances of the investment agreement;

- process of outlining of amendments;

- termination process; 
- process of the sanctions' application and a place of contemplation of the disputes arisen under the investment agreement.

In addition, depending on intrinsic features of particular invest project, investment agreement might contain other specific terms and requirements:

- Shared responsibilities of the sides on the improvement of both social structure and production capacity of the region;

- the right of investor which includes to export manufactured good from country and received profit as well

- responsibility of the investor to hire and train workforce from representatives of local population, in terms of using technologies and managing working process

In order to conclude investment agreement with government, the foreign investor should provide following document to responsible authority (in this case the Ministry of foreign economic relations, investments and trade of the Republic of Uzbekistan ):

- draft version of the investment agreement;

- fundamental measurements, in terms of economic, financial and technical side of the project, which is accepted by special body.

- Acceptance of Ministry of Justice in regard of the appropriateness of investment agreement to national legislature

- Acceptance of financial regulations, including Ministry of finance, the Ministry of economics and the State tax committee in regard of guaranteeing of tax privileges and preferences to foreign investors and newly formed enterprise with the share of foreign investor

In some particular cases when it is required the body can request some additional details on further evaluation of the draft.

The presented draft and other supplementary documents are considered by authorizes bodies within 14 working day from registered date. If necessary, with view to monitor provisions of the investment agreement between the regulator in the face of Ministry of foreign economic relations, investments and trade of the Republic of Uzbekistan and the foreign investor negotiations are approved.

After having signed by foreign investor and regulatory body, the agreement will be submitted by the latter to the government (Cabinet of Ministers of Uzbekistan) and requested for a relevant decision on its approval.

Signed by the foreign investor and the Ministry of foreign economic relations, investments and trade of the Republic of Uzbekistan the investment agreement, is submitted by the latter to the Cabinet of Ministers of the Republic of Uzbekistan for taking a relevant decision on its approval by the Government.

The investment agreement with the foreign investor starts to have licit power from the date when decision on its approval has been taken.

Supplementary guarantees and procedures of protection and privileges shall be given to foreign investors in particular situation if they invest following spheres: - priority divisions providing sustainable economic growth, enlightened essential modifications of a national economy; - priority projects providing establishment and development of industrial and an export prospective of the state; - projects in the sphere of small entrepreneurship which execution is targeted to aid the manufacture of consumer goods and services, maintenance of engagement of the people. («Procedure of investment agreements conclusion and fulfillment "UZINFOINVEST" the Information Support \& Foreign Investments Promotion Agency»)

\section{Preferences and opportunities for investors}

External fund raising in the Republic of Uzbekistan is discriminating with appropriate conditions that are provided to investors that support projects in Uzbekistan accomplished by legal bodies and natural persons that are preferable for every investor from third country.

Licit legislation enacted by the government in Uzbekistan as well as general warranties and routes of security that have destined on foreign investors, that can widely back investors from another countries are main contributors in such a attractiveness of this site alongside with permitting unconditional bilateral performance by partners. Numerous cases for allowing investors to raise finances that are given below represent investment agreement with expletive guarantees and measures of protection:

$\checkmark \quad$ Make a stress on particular projects that render assistance to enlargement and reinforcement in country's economic potential and its share on global market.

$\checkmark$ Domains proliferating great potential to maintain economic progress, therefore creating appropriate structural vicissitudes in local economy.

$\checkmark$ Contribution in facet of small business distinctively dedicated toward manufacturing raw materials, production of services and goods destined to consumers and providing local inhabitants with vocations.

Emanating from aforementioned features the Government of the Republic of Uzbekistan offers supplementary guarantees and procedures of safety and with bilateral agreement of sides contracts will be signed.

The Government of the Republic of Uzbekistan and the Ministry for Foreign Economic Relations, Investments and Trade of the Republic of Uzbekistan and the foreign investor will decide further concatenation of circumstance.

The rights of investors from third countries who conduct investment projects in Uzbekistan will be under protection of the government.

Once following legislation endorsed by the Republic of Uzbekistan, the apropos condition will be presented to foreign investors with long-term perspective of 10 years instituting from moment of consent. Investment date that confirmed by legislation act will be applied. Investor has been permitted to select new legislation consecrated to improving investment state within Uzbekistan by his/her own will.

Given legislation instructs the constant reclamation in timescale of 10 years' warranty. Thereby, at interim when descent investment environment is coming, foreign investor requires application of a guarantee from corresponding legal entity.

Par excellence, brand-new entrepreneurship with minimum \$5 million dollars cash share of foreign investors, as a result of potential changing tax laws can be harnessed by investors in period of 10 years from the date of governmental recording.

The state organizations including: Ministry of Foreign Affairs, Ministry of Internal Affairs, Ministry for Foreign Economic Relations, Investments and Trade, the State Tax 
Committee of Uzbekistan and the servicing banks are considering as authorized entities in state registration where foreign investors' guarantees will be notified in the form of application.

Announcement that delivered to foreign investor is the fundamental feature for the application done by authorized individual that destined to legislature of foreign investor at the time of raising funds.

The several cases of lessening of taxed income for legal entities accounting for amount of:

$\checkmark$ Approaches mostly devoted to intensifying of nucleus domains such as creating new construction, renovation of edifices and compositions used for manufacturing needs as well as payment of intentionally obtained credits with design to debilitate calculated depreciations in consummate tax phase, though with deduction of maximum $30 \%$ from taxed benefit.

$\checkmark$ Routes addressed for renovation and technological refurnishing of production, procuring finance to credits distributed toward new technological utensils, loaned object's reimbursement price with slight rebate of confirmed devaluation in a corresponding tax period. Shrinking of taxed base conducted in five year period inaugurating from commencement when lion's share of expenses spent to technological apparatus to starting utilization of them into production. However, once realization and free of charge transmission of novel technological instruments in border of 3 years from date of gaining, given benefits will lost in vain. In case of realization and gratis transfer of new technological equipment within three years from the moment of its obtaining, this privilege is annulled with the rehabilitation of duties on payment of income tax for the whole period of application of the privilege

Another stupendous fact is that, local producers of goods with aim to export manufactured commodities, one exception is raw materials, on basis of external currency in contempt of origin of the fabrication will be granted to:

$\checkmark$ Hefty $50 \%$ deductions of profit tax-in the case if the company transmits goods that should not get over $30 \%$ from entire production.

$\checkmark$ Modest 30\% rebate in income tax--if the company exports wares in interval from $15 \%$ to $30 \%$ from total sales.(«Economy and Trade / Investment Climate»)

Foreign investments in the Republic of Uzbekistan enjoy the national treatment which provides foreign investors with conditions not less favorable, than corresponding conditions for investments, made by legal entities and natural persons of the Republic of Uzbekistan.

The legislation, alongside with the general guarantees and measures of protection of foreign investors, may envisage additional guarantees and measures of protection, including providing unconditional performance by partners.

In some cases on the basis of concluding investment agreement additional guarantees and measures of protection can be given to foreign investors at investment in:

-the priority sectors providing steady economic growth, progressive structural changes of a national economy; -the priority projects providing strengthening and expansion of an export potential of the country, its integration into world economic relations;

-projects in sphere of small business oriented at processing of raw material and materials, production of consumer goods and services, providing population with employment.

In case the Government of the Republic of Uzbekistan provides the foreign investor with additional guarantees and measures of protection (privileges and preferences), without fail, the investment agreement shall be concluded.

The investment agreement shall be concluded on behalf of the Government of the Republic of Uzbekistan between the Ministry for Foreign Economic Relations, Investments and Trade of the Republic of Uzbekistan and the foreign investor.

Also, the state guarantees and protects the rights of the foreign investors carrying out investment activity within the Republic Uzbekistan.

In case the subsequent legislation of the Republic of Uzbekistan deteriorates investment environment to foreign investors, within ten years from the moment of investment, the legislation acted on date of investment shall apply. The foreign investor is entitled to apply at own discretion those provisions of the new legislation which improve investment environment.

The legislation stipulates the notifying order of use of a ten years' guarantee. Thus, at approach of deterioration investment environment, the foreign investor notifies the corresponding authorized body on application of a guarantee.

In particular, the newly established enterprises with foreign investment, in which the foreign investor's contribution in cash of not less than five million U.S. dollars, in case of changing tax laws may be used within 10 years from the date of state registration rules and regulations in the payment of income tax law those value-added tax (turnover of sales of goods and services), property tax, tax on improvement and development of social infrastructure, unified social tax, single tax, as well as mandatory contributions to the Republican Road Fund and reconstruction, repair and equipping of educational and medical institutions operating on the date of their registration.

Authorized agencies, which shall be notified of the application by a foreign investor guarantees are state organizations involved in state registration of legal entities - Ministry of Foreign Affairs, Ministry of Internal Affairs, Ministry for Foreign Economic Relations, Investments and Trade, the State Tax Committee of Uzbekistan and the servicing banks.

Notification to the foreign investor is the basis for the application of the authorized body for the foreign investor legislation in force at the date of investment.

In the framework of investment projects worth over U.S. \$ 50 million and the share of foreign investors is not less than 50 percent of the construction of the necessary external, outside the production site, engineering and communication networks at the expense of budget funds and other domestic sources of funding Taxed profit for legal entities is reduced for the amount of:

- means addressed to expanding of major production in the form of a new construction, reconstruction of buildings and erections used for production needs and payment of credits received for these purposes with deduction of depreciations calculated in a corresponding tax period, but not more than thirty (30) percents of taxed profit; 
- means addressed for modernization and technological reequipping of production, obtaining of new technologic equipment, payment of credits issued for the above purposes, compensation of the cost of a leased object with deduction of imposed depreciation in a corresponding tax period. Reduction of taxed base in carried out within five (5) years starting from a taxed period in which the above expenses were carried out and on technologic equipment from the moment of putting it into operation. In case of realization and gratis transfer of new technological equipment within three (3) years from the moment of its obtaining, this privilege is annulled with the rehabilitation of duties on payment of income tax for the whole period of application of the privilege.

SWOT analysis of investment climate in Uzbekistan
Moreover, the enterprises - domestic manufactures who export the produced goods (works, services) for the foreign currency, except raw materials, independently of the origin of production, are granted with:

$-50 \%$ reduction in the income (profit) tax - if the company exports not less than $30 \%$ of total amount of sales of produced goods (works, services);

$-30 \%$ reduction in the income (profit) tax - if the company exports from $15 \%$ up to $30 \%$ of total amount of sales of produced goods (works, services); 


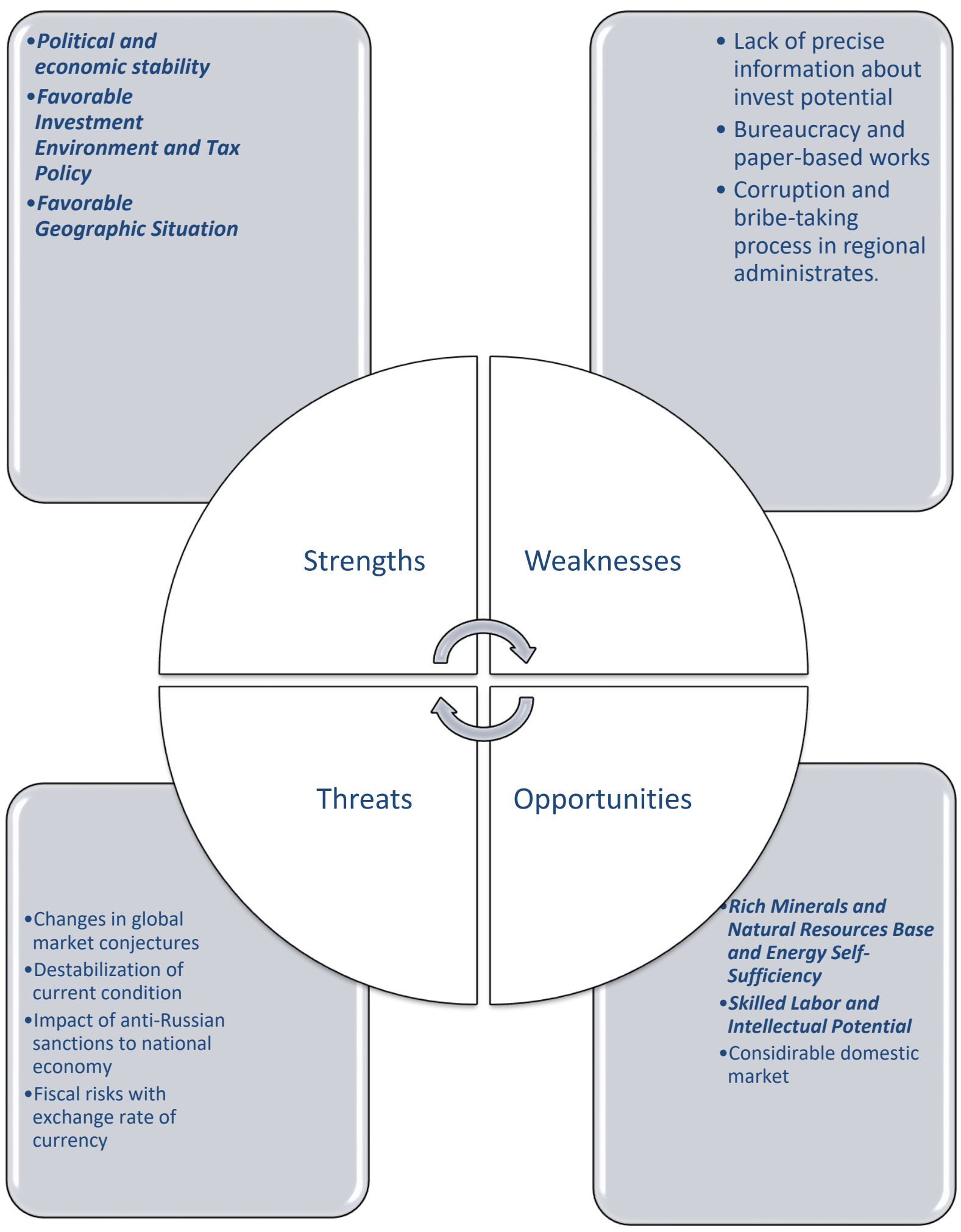

Figure 4. SWOT analysis of investment climate in Uzbekistan

As it can be glanced from SWOT analysis the first point which is considered as a key merit of country is political stability, sureness in future and reliability of reforms in all fields of public and political life. After collapsing the Soviet Union and obtaining 
independence Uzbekistan has done a great effort toward creating an attractive and safe environment for foreign investors and this thesis was included in the program called 'Uzbek Model' which was over accepted by both government and society. Due to successful implementation of this model in life, nowadays Uzbekistan has succeed and provided following opportunities:

$\checkmark$ Macroeconomic constancy, balance of domestic and foreign sectors of economy, rise of currency reserves;

$\checkmark$ Background for sustaining steady high rates of annual economic growth of GDP by $8 \%$ at average, prevalently, thanks to inner factors;

$\checkmark \quad$-decline of cumulative tax burden as much as 3 times, even more interestingly State is offering extra packages of concessions and preferences to exporting enterprises, small enterpreneurships and entities, making direct investments and launching new production;

$\checkmark$ establishment of sustainable banking and finance structures with severe adherence of Basel principles of banking supervision. Especially, one of the main indicators of stability of banking system - the degree of sufficiency of banking capital is estimated in region of $23 \%$, which is almost 3 times higher than global standards;

$\checkmark$ Advancement of novel forms of high technological industries through rigorous investment policy, technical transformation of manufacturing amenities and production substructures.

$\checkmark$ Another important factor which fortify the invest attractiveness of Uzbekistan is scrupulous financial policy of state that guarantee Steady Budget surplus for the last few years.

For the last few decades, Uzbekistan created a range amount of juridical guarantees and preferences for foreign investors, advanced fundamental system of evaluation on reinforcement of enterprises with directly linked to foreign investments. According to latest modifications in legal system, the state guarantees and protects the jus of foreign investors, which execute investment activity within the Republic of Uzbekistan. In order to prevent any kind of misrepresenting, the legislature dictate that in the event, the consequent legislation of Uzbekistan makes investment environment less favorable, then, within 10 years from the moment of venture, foreign investors will be managed by the legislation, which was in power in the date of investment negotiation. Upon its preference, after informing the authorities, the foreign investor is permitted to apply those provisions of new regulation which make the investment climate more desirable.

Furthermore, in some events, foreign investors could be provided with additional warranties and evaluation of defense of lex in the event when investor puts its sources into particular sectors and industries, which is regarded as priority and salutary for sustainable economic growth, reinforcement and augmenting, export potential of the country and also projects which related with development of small enterprises.

Representatives of small enterprises and private ownership businesses are provided with the range of priveleges and exceptional advantages on the domains of taxation and loans. According to statistics for 1996-2015, tax rates for small businesses and private enterprises decreased from $38 \%$ down to $7 \%$ or as much as 5.4 times in other words. In acquiescence with the Taxation Measuring System of country, micro-firms and small businesses are entitled to select oversimplified system of taxation, which enables to pay amalgamated tax instead of generally recognized range of taxes and other obligatory charges. Even more dramatically, for lessening of the tax burden for small enterprises and private businesses and with target of their monetary support, for the last 5 years, the rate of amalgamated tax was plunged by 6 per cent items from $13 \%$ in 2005 to $6 \%$ in 2011. («Why Uzbekistan | "UZINFOINVEST" the Information Support \& Foreign Investments Promotion Agency», б. д.)

As a part of Central Asia, Uzbekistan is one of the prominent states of the world according to its mineral and natural reserves of gold, uranium, copper, silver, zinc, tungsten, rare metals, natural gas, coal and fossil minerals. Besides, access to vast amount of supplies extremely optimizes the manufacturing costs by considerable lessening of carrying costs for commodities and raw materials, establishes proficiencies for deeply configuration and processing with manufacture of products. Since Uzbekistan revealed about 3000 deposits and potential depositions of minerals and natural sources, with overall mineral-feed potential of the state assessed more than US\$ 3.5 trillion. This fact is obviously glanced at the main role among main producers of traditional commodities, where Uzbekistan regarded as one of the leading states in the world occupying $11^{\text {th }}$ position by reserves of copper, and $7^{\text {th }}$ place in production of gold and uranium as well as one of the five leaders by production of cotton fiber. («Uzbekistan opportunities Embassy Of The Republic Of Uzbekistan»)

However, the paramount advantage of Uzbekistan among other developing and developed countries in terms of invest attractiveness, particularly in heavy industry, is energy selfsufficiency of the economy, which is very rare occasion, which includes the country in the small group of countries of the globe that also classified as Uzbekistan. Equally importantly, the Republic is currently listed among TOP 10 countries of the world in terms of reserves of raw materials like gas, coal, uranium and exporting them. Collective reserves of energy carriers of Uzbekistan are adequate to fulfil requirements of the national economy at least for one century. Electricity produced in Uzbekistan completely covers exponential rising needs of the country and population and furthermore its actual price is 4 times lower when comparing with average cost paid by the business consumers in developed and some developing countries.

Another main advantage of is certainly qualified and skilled work forces available in country. As maximum part of population are well educated according to over accepted contemporary standards of education in order to challenge with present day tasks. Unique and exceptional by its meaning concept provided by National Program guarantee the persistent and up-to-date general education and professional training.

In contrary, SWOT analysis also reveals some challenges and shortcoming of status quo of investment perspective of Uzbekistan created mainly by both internal and external factors. One of the main drawbacks which barriers development of investment is deficiency of precise data and clear evidences of investment potential. Nonattendance of Uzbek business establishment in various international fairs and shows and hence absence of clear imagination of prospective of national economy among foreign investors. Another main contributing factor is bureaucracy in some administrative bodies, when obtaining some 
permissions or other licit acts in order to start up entrepreneurships takes much more time than it presented in legislature due to deliberate attempt to prolong this process by some responsible bodies which linked with another equal important cause corruption and bribe-taking procedure in many branches of administration. Despite the endeavors of government which make clear and simplified procedure of registration new entities of both with participation of foreign investment and without it as well as establishing strict the anti-corruption norms, country is still listed among countries where rate of corruption is higher than average index. («Blurring the line between licit and illicit: transnational corruption networks in Central Asia and beyond 02634937.2015.1010799»)

Main fears, which is labelled as actual, are connected mainly with external threats rather than internal conditions. The most serious issue which has direct impact on national economy is volatility of international market situation, particularly case of sanctions executed against the main trade partner of country Russian Federation. Anti-Russian sanctions serves to lessening the turnover between two strategic partners and as a result reducing amount of financial sources to income of Uzbekistan. In addition, problems with non-evident exchange rate and existing of shadow systems on fiscal policy also cause to potential risk to current stable condition in country. country

Proposals for further improving of invest appealing of

Detailed scrutiny of main tendencies in economy as whole and investment sphere in particular as well as government policies and labor potential the researchers of different world renowned organizations and responsible bodies of country make following suggestions which might directly serves as a way of further development of investment prospects of country:

1. In spite of deterioration of global market conjectures, the country's economic performance was excitingly high due to strong monetary and outward position as well as stable banking system and negligible rate of public debt. However, the quantity of import goods was pushed by external capital and present account surplus rose slightly and global reserves continued to be high.

2. The associated fiscal and monetary position was better than accounted, aiding from complex tax collection and spending in line with the state budget in the first part of 2014. Despite a fall in gold and copper prices, the governmental Fund for Reconstruction and Development's income surpassed spending by 4.3 percent of January-July indexes of GDP.

3. After reaching a peak point at 12.8 percent in May 2013 in regard of annual inflation and the index of inflation decreased significantly(11,3 percent in August of the same year). However, inflation in country remains high and responsible bodies like Central Bank of Uzbekistan and Ministry of Finance should optimize the process of currency exchange and make it more open.

4. As depreciation of national currency is high, monetary policy should be more accommodative. Supported by directed loaning and strong national activity, the growth of credit to the economy remained at 30 percent through the years. Making flexible rate connected which connected with current exchange index rather than nominal index is considered as one of the possible solutions.

5. Even banking system remained steady, well capitalized, and highly liquid and integration with global financial organizations is the main tendency of state monetary policy and engagement with IMF and World Bank's technical assistance, focused on solidification of provident regulations, on- and off-site supervision is in process, researchers propose to make the system more clear and glanced. By providing and strengthening relation with public and evident statistics of bank, the financial institutions can improve their revenue.

6. The short-term economic outlook is favorable and the principal risks remain controllable. It is obviously seen in the large scale modernization and diversification investment program. After predictable high performance of national in 2014 of 8 percent the government is projecting high GDP growth in region of 7,5 percent in the following year, based on their own evaluation of the possible limited effect of external situation on the national economy and made an action plan and measures on the worst-case scenario. Nevertheless, the government should also take into account the possible sanction on the priority trade partner of country - Russia, as it seems the barrier between Russia and West is going up and this tendency creates undesirable risk for economic performance of country.

7. Going forward by strong policy of lessening the rate of inflation remains a key point of macroeconomic policy. Reducing the rate inflation cardinally and hold it in sustainable region of two digits involves synchronized endeavors in the comportment of monetary, fiscal, and foreign exchange policy of country. The regulator bodies should constrict monetary policy, prevent fiscal loosening, and upsurge the exchange rate flexibility.

8. The authorial bodies should take benefit of their status quo strong position by accelerating structural reforms, which help to proliferate productivity, promote the modernization and diversification and augment competitiveness among entrepreneurial subjects in order to fortify sustainable and continuous growth.

9. Success in improving the business environment and governance hinges on the authorities' determined implementation of these measures in practice as planned.

10. Progress with reinforcement monetary and fiscal statistics, which is successfully implementing currently, is concerned as a well-planned action. However, in order to make a further oversimplification and glance their annual statistics it is suggested to enhance their participating in General Data Dissemination System by opening a country page in International Financial Statistics and distributing up-to-date monetary data in the Government Financial Statistics Yearbook. This activity could be implemented more intensively with the help of international financial institutuions such as International Monetary Fund and World Bank 


\section{REFERENCES}

[1] B. B. Valiev. (2014). FOREIGN DIRECT INVESTMENT POLICY AND TRENDS IN UZBEKISTAN. Vědecko vydavatelské centrum «SociosféraCZ», s.r.o., 2014., cc. 93-97.

[2] Blurring the line between licit and illicit: transnational corruption networks in Central Asia and beyond - 02634937.2015.1010799. (б. д.). Извлечено от http://www.tandfonline.com/doi/pdf/10.1080/02634937.2015.1010799

[3] By Industry | "UZINFOINVEST" the Information Support \& Foreign Investments Promotion Agency. (б. д.). Извлечено 10 май 2015 г., от http://www.uzinfoinvest.uz/eng/investment_opportunities/by_industry/ener gy_sector/

[4] Economy and Trade / Investment Climate. (б. д.). Извлечено 10 май 2015 Г., от http://www.uzbekistan.org/economy_and_trade/climate/

[5] Industry - Uzbekistan. (б. д.). Извлечено 10 май 2015 г., от http://www.uiic.co.uk/investment-in-uzbekistan/history/

[6] Macroeconomic indicators of the Republic of Uzbekistan. (б. д.). Извлечено 26 апрель $2015 \quad$ г., от http://stat.uz/en/index.php/88-interaktivnyeuslugi/773-macroeconomic-indicators-of-the-republic-of-uzbekistan

[7] MFERIT - Promising investment projects. (б. д.). Извлечено 26 апрель 2015 г., от http://www.mfer.uz/en/investments/investment-projects/

[8] MFERIT - Statistics investing activities. (б. д.). Извлечено 26 апрель 2015 Г., от http://www.mfer.uz/en/investments/statistics/

[9] Parpiev. (2014). New horizons in the development of oil and gas industry: Case of Uzbekistan. Молодой ученый. Извлечено от http://www.moluch.ru/archive/76/13000/
[10] Procedure of investment agreements conclusion and fulfillment | "UZINFOINVEST" the Information Support \& Foreign Investments Promotion Agency. (б. д.). Извлечено от http://www.uzinfoinvest.uz/eng/investment_guide/procedure_of_investment _agreements_conclusion_and_fulfillment/

[11] Structure of Uzauto. (б. д.). Извлечено от http://uzavtosanoat.uz/strukturacentralnogo-apparata.html

[12] Structure of Uzbekneftgaz. (б. д.). Извлечено от http://www.ung.uz/about/structure

[13] Uzbekistan opportunities | Embassy Of The Republic Of Uzbekistan. (б. д.). Извлечено от http://www.uzbekembassy.ae/business_uzbekistan.php

[14] Uzbekistan population 2015 Current population of Uzbekistan. (б. д.). Извлечено 10 май 2015 г., от http://countrymeters.info/en/Uzbekistan

[15] Vladimir Popov. (2014, декабрь). CAN UZBEKISTAN ECONOMY RETAIN ITS HIGH GROWTH RATE? SCENARIOS OF ECONOMIC DEVELOPMENT IN 2015-30. New Economic School. Moscow.

[16] Why Uzbekistan |"UZINFOINVEST" the Information Support \& Foreign Investments Promotion Agency. (б. д.). Извлечено 10 май 2015 г., От http://www.uzinfoinvest.uz/eng/why_uzbekistan

\section{AUTHORS}

First Author - Mukhammadkhon Soliev, Innovative Center, Head of Academy, E-mail: muhammadsoliyev@ hotmail.com 